10IKC-253

\title{
ORIGIN AND EVOLUTION OF CRATONIC ROOTS
}

\author{
DG Pearson ${ }^{1}$, KA Mather ${ }^{2}$, A. Ishikawa ${ }^{3}$, B.A. Kjarsgaard ${ }^{4}$ \\ 1. Department of Earth \& Atmospheric Sciences, University of Alberta, Edmonton, T6G 2E3, Canada \\ 2. Department of Earth Sciences, Durham University, Durham, UK \\ 3. Department of Earth Science and Astronomy, The University of Tokyo, Tokyo, Japan \\ 4 Geological Survey of Canada, Ottawa, Canada.
}

\section{INTRODUCTION}

Over the last 20 years two dominant models for the origin of cratonic roots have evolved. One model involves peridotite melting in a plume environment, with vertical accretion of thick cratonic roots from below (e.g., Boyd, 1989; Pearson et al., 1995; Griffin \& O'Reilly, 2008; Aulbach et al., 2011), sometimes adding to previous lithosphere of oceanic (or shallow melting) origin (Griffin et al., 1999). A second model constructs cratonic roots via either subduction and lateral thickening of highly depleted residues produced at ridges and/or subduction zones (e.g., Helmstaedt, H., and Schulze, D.J., 1989; Canil, 2004; Simon et al., 2007; Pearson \& Wittig, 2008). In such a model, eclogites represent subducted oceanic crust (e.g., Taylor \& Neal, 1989; Jacob, 2004; Tappe et al., 2011).This contribution examines the phase equilibria, geochemical and geochronological evidence for these different models, using constraints from their modern day analogue plate tectonic settings.

\section{CHEMICAL EVIDENCE FOR CRATON FORMATION}

The geochemical signatures of cratonic peridotites are very difficult to interpret because of multiple metasomatic events that may have introduced numerous different phases, such as orthopyroxene (Opx), clinopyroxene and some garnet into cratonic residues. This makes major element bulk compositions particularly problematical in estimating the depth of melting. Taken at face value, major elements can be used to support a high-P melting origin if the low $\mathrm{FeO}$ of cratonic peridotites (Boyd, 1989) is taken as a primary signature (e.g., Aulbach et al., 2010). Alternatively, low FeO may be a product of Opx addition (e.g., Simon et al., 2007). If the effects of Opx enrichment are estimated and subtracted, then using bulk $\mathrm{FeO}-\mathrm{MgO}$ relations yields average pressures of melting at circa $3 \mathrm{GPa}$ with a very large spread. Given the scatter in compositions it is very difficult to interpret, with any confidence, the bulk rock $\mathrm{FeO}-\mathrm{MgO}$ as representing polybaric melting trends of closely related suites of melting residues. Further evidence of the difficulty in using bulk rock $\mathrm{FeO}-\mathrm{MgO}$ relations comes from orogenic peridotites that have not been subject to the intensive pyroxene and garnet enrichment events seen in some cratonic peridotites. Peridotites from single massifs, sampled within a few $\mathrm{km}$ of each other show large, irregular variations in $\mathrm{FeO}$ that cannot sensibly be related to variations in melting pressure at this sampling scale. Despite the lack of obvious evidence for metasomatism these peridotites appear to have been subject to melt-related interaction that has disturbed $\mathrm{FeO}$, rendering it inappropriate as an accurate indicator of melting pressure.

Another indicator that has been used extensively for addressing the petrogenesis of 


\section{0 $^{\text {th }}$ International Kimberlite Conference, Bangalore - 2012}

cratonic peridotites is the mg-number of olivine (Boyd, 1989; Bernstein et al., 2006; Pearson \& Wittig, 2008). This parameter is also subject to the effects of processes such as Opx addition and must be viewed with caution. Nonetheless, the uniformity in olivine compositions amongst low$\mathrm{T}$ cratonic peridotites is striking.

The high and consistent mg-number mode of 92.6 highlights the unusually uniform depletion in cratonic peridotites, indicating that whichever melting environment they were produced in, the evidence for the polybaric melting behavior that must have taken place has largely been lost or over-printed.

Perhaps the closest modern analogues to the plume end-member model for cratonic peridotite genesis are the peridotites from the edge of the Ontong-Java plateau (OJP), sampled by the Malaita alnoite. These peridotites display evidence for a 2-layer structure of the (OJP) lithosphere, with the more consistently depleted, plume-related peridotites underlying less depleted oceanic lithosphere (Ishikawa et al., 2011). Hence, this occurrence could be an analogue for some compositionally layered cratonic lithosphere such as that beneath the Slave craton (Griffin et al., 1999; Kopylova \& Caro, 2004). While attractive at face value, $\mathrm{FeO}-\mathrm{MgO}$ systematics place the majority of melting pressures between 4 and $<2 \mathrm{GPa}$ for central Slave lherzolites. Despite these contradictions, there is much to be learned from such modern analogues and this study will extend the comparative study.

New studies in the N. Slave craton suggest instances where lithospheric thin-spots in cratons have become thickened by post-Archean lithosphere of similar composition to cratonic lithosphere. In this situation, the most viable mechanism of new lithosphere generation seems to be via mantle upwelling and melting associated with the Mckenzie large igneous event (Mather et al., in prep).

Further work needs to be undertaken to address deficiencies in both end-member genetic models for craton formation. A key issue to be resolved in both models is the fate of eclogitic material (Pearson \& Wittig, 2008). Eclogites representing subducted oceanic lithosphere must be cleansed from the accreted lithosphere via unconstrained mechanisms in the lateral acretion and stacking model. In models invoking TTG production above oceanic plateau the eclogite restite must be continuously lost gravitational sinking, in the latter stages through depleted protocratonic mantle (Bedard, 2006). In any model for craton evolution, lateral accretion must play a significant role in final amalgamation of cratonic nuclei into the larger coherent cratons that we see today.

\section{LITHOSPHERE EVOLUTION AND THE GEOTHERM}

Thickness estimates of cratons and their attendant geotherms, at the time of kimberlite eruption, can now be more quantitatively compared using the FITPLOT method (McKenzie et al., 2005; Mather et al., 2011). This approach indicates avariability in thickness, from circa $175 \mathrm{~km}$ to $240 \mathrm{~km}$ and show significant vertical thickness gradients at their margins that may control their stability and the location of kimberlitic and other magmas. We can also make more accurate estimations of rates of lithosphere thinning. For instance, the lithosphere beneath the Gibeon kimberlite field can be shown to have been of similar thickness to that beneath the western portion of the Kaapvaal craton at the time of kimberlite eruption whereas seismological estimates show a loss of approximately $50 \mathrm{~km}$ of lithosphere since that time (Mather et al., 2011). Using these tools we investigate other instances of craton thinning, to examine possible mechanisms of craton destruction.

\section{References}

Aulbach, S., Stachel T., Heaman L.M., Creaser R.A., Shirey S.B. (2011) Formation of Cratonic 


\section{0 $^{\text {th }}$ International Kimberlite Conference, Bangalore - 2012}

Subcontinental Lithospheric Mantle from Hybrid Plume Sources. Contributions to Mineralogy and Petrology: 161: 947-960.

Bedard, J. (2006) A catalytic delamination-driven model for coupled genesis of Archaean crust and sub-continental lithospheric mantle. Geochimica et Cosmochimica Acta, 70, 1188-1214.

Bernstein, S., Kelemen, P.B. \& Hanghøj, K. (2006) Consistent olivine $\mathrm{Mg \#}$ incratonic mantle reflects Archean mantle melting to the exhaustion oforthopyroxene. Geology, 35, 459-462.

Boyd, F.R. (1989) Compositional distinction between oceanic and cratonic lithosphere. Earth \& Planetary Science Letters, 96, 15-16.

Canil, D. (2004) Mildly incompatible elements in peridotites and the origins of mantle lithosphere. Lithos, 77, 375-394.

Griffin, W. L., Doyle, B. J., Ryan, C. G., Pearson, N. J., O'Reilly, S. Y., Davies, R., Kivi, K., van Achterbergh, E. \& Natapov, L. M. (1999). Layered mantle lithosphere in the Lac de Gras Area, Slave Craton: composition, structure and origin. Journal of Petrology 40, 705-727.

Griffin, W.L. \& O’Reilly, S. (2008) Cratonic lithosphere: Is anything subducted? Episodes, 30, 43-53.

Helmstaedt, H., and Schulze, D.J., 1989, SouthernAfrican kimberlites and their mantle sample:Implications for the Archaean tectonics andlithosphere evolution: Geological Society ofAustralia Special Publication 14, p. 358-368.

Ishikawa, A., Pearson, D.G. \&Dale, C. (2011) Ancient Os isotope signatures from the Ontong Java Plateau lithosphere: tracing lithospheric accretion history. Earth \& Planetary Science Letters. 301, 159-170.

Jacob, D. (2004) Nature and origin of eclogite xenoliths from kimberlites. Lithos, 77, 295-316.

Kopylova, M.G. \& Caro, G. (2004) Mantle Xenoliths from the Southeastern Slave Craton: Evidence for Chemical Zonation in a Thick, Cold Lithosphere. Journal of Petrology, 45, 045-1067.

Lee, C.-T.A., 2006, Geochemical/petrologic constraintson the origin of cratonic mantle, inBenn, K., et al., eds., Archean geodynamics andenvironments: American Geophysical UnionGeophysical Monograph 164, p. 89-114.
Mather, K.A., Pearson, D.G., McKenzie, D.P., Kjarsgaard, B.A. \& Priestley, K. (2011) Constraints on the depth and thermal history of cratonic lithosphere from peridotite xenoliths, xenocrysts and seismology, Lithos, 125, 729-742.

Mather, K.A., Pearson, D.G., Kjarsgaard, B.A., Dale, C.W., Jones, A., Kopylova, M., Armstrong, J.A., Jackson, S., Irvine, G. (in prep) Lithospheric replacement in the Northern Slave Craton geochemical and geophysical evidence. Earth \& Planetary Sciences Letters.

McKenzie, D., Jackson, J., Priestley, K., 2005. Thermal structure of oceanic andcontinental lithosphere. Earth and Planetary Science Letters 233, 337-349.

Nixon, P. H. \& Boyd, F. R. (1979). Garnet bearing lherzolites and discrete nodule suites from the Malaita alnöite, Solomon Islands, S.W. Pacific, and their bearing on oceanic mantle composition and geotherm. In: Boyd, F. R. \& Meyer, H. O. A. (eds) The Mantle Sample: Inclusions in Kimberlite and Other Volcanics. Washington, DC: American Geophysical Union, pp. 400-423.

Pearson, D.G. \&Wittig, N. (2008) Formation of Archean continental lithosphere and its diamonds: The root of the problem. Journal of the Geological Society, London, 165, 1-20.

Pearson, D. G., Carlson, R. W., Shirey, S. B., Boyd, F. R., and Nixon, P. H., 1995, Stabilisation of Archaean lithospheric mantle; a Re-Os isotope study of peridotite xenoliths from the Kaapvaal Craton: Earth and Planetary Science Letters, v. 134, p. 341-357.

Simon N.S.C. Carlson R.W., Pearson D.G. and Davies G.R., (2007). The origin and evolution of the Kaapvaal cratonic lithospheric mantle. J. Petrology, 48, 589-625.

Tappe, S., Smart, K.A., Pearson, D.G.,Steenfelt, A. Simonetti, A. (2011) Craton formation in Late Archean subduction zones revealed by first Greenland eclogites. Geology, 39, 1103-1106.

Taylor, L.A. \& Neal, C.R. (1989) Eclogites with oceanic crustal and mantle signatures from the Bellsbank kimberlite, South Africa. Part 1: mineralogy, petrography and whole rock chemistry. Journal of Geology, 97, 551-567. 